\title{
Replacement of cellular potassium by caesium in Chlorella emersonii: differential sensitivity of photoautotrophic and chemoheterotrophic growth
}

\author{
Simon V. Avery, Geoffrey A. Codd and Geoffrey M. GadD* \\ Department of Biological Sciences, University of Dundee, Dundee DDI 4HN, UK
}

(Received 30 May 1991; revised 28 August 1991; accepted 17 September 1991)

\begin{abstract}
Photoautotrophic growth of Chlorella emersonii in the presence of $1 \mathrm{mM}-\mathrm{CsCl}$ resulted in a $34 \%$ increase in cell doubling time and an $83 \%$ reduction in the final cell yield as compared to growth in the absence of $\mathrm{Cs}^{+}$. In contrast, the presence of $1 \mathrm{mM}-\mathrm{Cs}^{+}$had no effect on chemoheterotrophic growth in the dark with glucose. These observations were correlated with the stage of growth at which $\mathrm{Cs}^{+}$-induced cellular $\mathrm{K}^{+}$loss was evident. For photoautotrophically growing cells this occurred during the exponential growth phase (after $4 \mathrm{~d}$ ); for chemoheterotrophically growing cells this was during stationary phase (after $10 \mathrm{~d}$ ). Inhibition of chemoheterotrophic cell division occurred after $2 \mathrm{~d}$ in $50 \mathrm{mM}-\mathrm{Cs}^{+}$or $5 \mathrm{~d}$ in $20 \mathrm{mM}-\mathrm{Cs}^{+}$, and coincided with a decline in intracellular $\mathrm{K}^{+}$to $\sim 2 \mathrm{nmol}\left(10^{6} \text { cells }\right)^{-1}$. Accumulation of $\mathrm{Cs}^{+}$ceased after $2 \mathrm{~d}$ in both of these cases. Cell doubling times during chemoheterotrophic growth remained approximately constant at internal $\mathrm{K}^{+}$levels between 7 and $28 \mathrm{nmol}$ $\left(10^{6} \text { cells }\right)^{-1}$. In contrast, a decline in intracellular $\mathrm{K}^{+}$, from 42 to $19 \mathrm{nmol}\left(10^{6} \text { cells }\right)^{-1}$, after $4 \mathrm{~d}$ photoautotrophic growth in the presence of $\mathrm{Cs}^{+}$, was concurrent with the $34 \%$ increase in cell doubling times. Photosynthesizing cells accumulated approximately 2 -fold more $\mathrm{Cs}^{+}$than respiring cells after incubation for $12 \mathrm{~h}$ in HEPES buffer, $\mathrm{pH} 8$. Culture age and intracellular $\mathrm{K}^{+}$levels had little effect on the ability of $C$. emersonii to accumulate $\mathrm{Cs}^{+}$. Externally supplied $\mathrm{K}^{+}$inhibited $\mathrm{Cs}^{+}$accumulation to a greater extent in photosynthesizing cells $(75 \%$ inhibition at $10 \mathrm{mM}-$ $\left.\mathrm{K}^{+}, 1 \mathrm{mM}-\mathrm{Cs}^{+}\right)$than in respiring cells $\left(50 \%\right.$ inhibition at $\left.10 \mathrm{mM}-\mathrm{K}^{+}, 1 \mathrm{mM}-\mathrm{Cs}^{+}\right)$. Greatly elevated $\mathrm{Na}^{+}$ concentrations $(50 \mathrm{mM})$ were required to inhibit $\mathrm{Cs}^{+}$accumulation in both cases. Incubation of cells in buffer in the light in the absence and presence of $10 \mathrm{mM}-\mathrm{Cs}^{+}$resulted in decreases in cellular $\mathrm{K}^{+}$of $44 \%$ and $77 \%$ respectively and a concomitant $66 \%$ reduction in the rate of photosynthesis in both cases. $\mathrm{A} \mathrm{Cs}{ }^{+}$-induced $\mathrm{K}^{+}$loss of $71 \%$ from respiring cells had no effect on the rate of respiration. These results indicate that it is not the presence of $\mathrm{Cs}^{+}$in cells that is growth inhibitory, but rather the resulting loss of $\mathrm{K}^{+}$and that photosynthesis and photoautotrophic growth are more sensitive to this $K^{+}$loss than respiration and chemoheterotrophic growth.
\end{abstract}

\section{Introduction}

Caesium is a nuclear fission product that is of particular environmental importance due to the long half-life of the radioisotope (approximately 30 years) and the high water solubility and bioavailability of the monovalent caesium ion, $\mathrm{Cs}^{+}$(Greenwood \& Earnshaw, 1984). For the latter reason, in vivo studies on the accumulation of ${ }^{137} \mathrm{Cs}$ into living biomass have been used as a means of determining natural levels of the isotope and such studies have intensified since the Chernobyl accident in 1986 (Cambray et al., 1987; Elstner et al., 1987). Little is known, however, about the mechanisms of $\mathrm{Cs}^{+}$transport - in particular, $\mathrm{Cs}^{+}$transport into microbial cells which play significant roles in the accumulation, cycling and transfer of heavy metals and radionuclides in the environment (Gadd, 1988, 1990; Hughes \& Poole, 1989).
The high concentration of ${ }^{137} \mathrm{Cs}$ in radioactive wastewaters from power reactors (Watson et al., 1989) indicates that aquatic ecosystems are especially susceptible to contamination with caesium. In aquatic environments, microalgae and cyanobacteria are important microbial primary producers and of these, Chlorella spp. have been used as a suitable test organism for toxicity and transport studies with heavy metals and radionuclides (Nakajima et al., 1981 ; Khummongkol et al., 1982; Mahan et al., 1989; Bennett, 1990). Caesium transport in Chlorella is relevant to studies with monovalent cations as $\mathrm{Cs}^{+}$is known to be transported via $\mathrm{K}^{+}$transport systems in other micro-organisms, e.g. bacteria (Bossemeyer et al., 1989), cyanobacteria (Avery et al., 1991) and yeast (Borst-Pauwels, 1981). Two $\mathrm{K}^{+}$transport systems have been shown to occur in Chlorella (Kannan, 1971; Solt et al., 1971): a high-affinity system which permits 
net $\mathrm{K}^{+}$influx and a low-affinity system which determines $\mathrm{K}^{+} / \mathrm{K}^{+}$exchange (Paschinger \& Vanicek, 1974). Raven (1980) concluded that $\mathrm{K}^{+}$influx in Chlorella is probably via a uniport mechanism, although some evidence has suggested that $\mathrm{K}^{+} / \mathrm{H}^{+}$exchange may also occur (Schaedle \& Jacobsen, 1965; Tromballa, 1981).

The nutritional versatility displayed by several Chlorella species in their ability to grow both photoautotrophically and chemoheterotrophically is apparently matched by a versatility in their $\mathrm{K}^{+}$requirements and transport mechanisms. Under certain conditions in the natural environment, for example in densely populated algal communities, light and $\mathrm{CO}_{2}$ are limiting factors for growth and, as a consequence, heterotrophic algae may become dominant (Droop, 1974). Eyster et al. (1958) observed that a tenfold higher external $\mathrm{K}^{+}$concentration is required for heterotrophic growth of Chlorella than for autotrophic growth. It is known that cyclic photophosphorylation supports a higher rate of $\mathrm{K}^{+}\left(\mathrm{Rb}^{+}\right)$uptake than oxidative phosphorylation of endogenous substrates (Barber, 1968a, b; Kannan, 1971); however, this situation is reversed when glucose is supplied as an exogenous organic carbon source (Springer-Lederer \& Rosenfeld, 1968).

The possibility that photoautotrophic and chemoheterotrophic growth regimes may influence the accumulation and toxicity of $\mathrm{Cs}^{+}$towards Chlorella emersonii 211 $8 \mathrm{~b}$ was investigated in this study, together with interactions of $\mathrm{Cs}^{+}$with cellular $\mathrm{K}^{+}$. In addition, the inhibition of photosynthesis and respiration following $\mathrm{Cs}^{+}$accumulation was examined.

\section{Methods}

\footnotetext{
Organism, media, growth conditions and preparation of cell suspensions. Axenic cultures of Chlorella emersonii $2118 \mathrm{~b}$ were grown at $22^{\circ} \mathrm{C}$ in $100 \mathrm{ml}$ of BG-11 medium (initial $\mathrm{pH} \sim 7.6$ ), containing nitrate as a fixed nitrogen source (Stanier $e$ t al., 1971). Cultures were incubated in

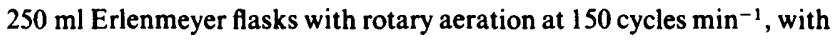
a photon fluence irradiance, incident on the surface of the flasks, of $12 \mu \mathrm{E} \mathrm{m}^{-2} \mathrm{~s}^{-1}$, provided by white fluorescent tubes.

For growth experiments, cells in the late exponential phase of photoautotrophic growth were inoculated to an initial cell density of approximately $2.7 \times 10^{5} \mathrm{ml}^{-1}\left(\mathrm{OD}_{680} \approx 0.1\right)$ in $100 \mathrm{ml}$ of BG-11 medium for autotrophic growth or $100 \mathrm{ml}$ of BG-11 medium and $1 \%$ $(w / v)$ glucose for heterotrophic growth, containing the desired amounts of $\mathrm{Cs}^{+}$(added as $\mathrm{CsCl}$ ). These were incubated as above except black polythene was used to eliminate incident light in chemoheterotrophic growth.

To prepare cell suspensions for short-term $\mathrm{Cs}^{+}$uptake experiments, cells in the late exponential growth phase (unless otherwise specified) were collected by centrifugation $(1200 \mathrm{~g}, 10 \mathrm{~min})$, washed thoroughly with distilled deionized water and then suspended to a cell density of approximately $5 \times 10^{6} \mathrm{ml}^{-1}$ in $100 \mathrm{ml} 10 \mathrm{mM}$-HEPES buffer $\pm 1 \%$ (w/v) glucose, adjusted to $\mathrm{pH} 8$ using solid tetramethylammonium hydroxide. Cells were allowed to equilibrate for $1 \mathrm{~h}$ prior to addition of $\mathrm{Cs}^{+}$and/or other monovalent cations. All cell suspensions were
}

incubated at $22{ }^{\circ} \mathrm{C}$ with rotary shaking $\left(150\right.$ cycles $\left.\min ^{-1}\right)$ in the presence or absence of light as described above. All glassware was washed with $1 \mathrm{M}-\mathrm{HCl}$ and rinsed thoroughly with distilled deionized water prior to use.

Measurement of photosynthesis and respiration. Photosynthesis and respiration by $C$. emersonii cell suspensions were measured at $25^{\circ} \mathrm{C}$, either in the light at a photon fluence irradiance of $250 \mu \mathrm{E} \mathrm{m}^{-2} \mathrm{~s}^{-1}$ for photosynthesis or in the dark with $1 \%(\mathrm{w} / \mathrm{v})$ glucose for respiration, using a Rank oxygen electrode linked to a Servoscribe potentiometric recorder. The chamber volume used was $3 \mathrm{ml}$ and calibration was by means of air-saturated distilled water; oxygen solubility values were obtained from Golterman (1969).

Metal analyses. Cells were harvested by centrifugation $(1200 \mathrm{~g}$, $10 \mathrm{~min}$ ) and washed twice with distilled deionized water. Cell pellets were digested for $1 \mathrm{~h}$ in $0.5 \mathrm{ml} 6 \mathrm{M}-\mathrm{HNO}_{3}$ at $100^{\circ} \mathrm{C}$ and, after subsequent addition of $2.5 \mathrm{ml}$ distilled deionized water and mixing, cell extracts were centrifuged $(1200 \mathrm{~g}, 10 \mathrm{~min})$ to remove debris. Caesium, potassium and sodium concentrations in the supernatants were determined using a PYE Unicam SP9 atomic absorption spectrophotometer with reference to appropriate standards.

\section{Results}

Effect of $\mathrm{Cs}^{+}$on photoautotrophic and chemoheterotrophic growth of C. emersonii and on cellular $\mathrm{K}^{+}$and $\mathrm{Na}^{+}$

Addition of $\mathrm{CsCl}$ to a final concentration of $1 \mathrm{~mm}$ in BG11 medium resulted in inhibition of photoautotrophic growth of $C$. emersonii. The cell doubling time during the exponential phase of growth was increased by approximately $34 \%$ from $1.60 \mathrm{~d}$ to $2.15 \mathrm{~d}$ and the final cell yield after incubation for $35 \mathrm{~d}$ was reduced by approximately $83 \%$ (Fig. 1a). Chemoheterotrophic growth of $C$. emersonii was considerably faster than photoautotrophic growth and was exponential over the first $6 \mathrm{~d}$, with a doubling time of $0.9 \mathrm{~d}$, reaching stationary phase after $10 \mathrm{~d}$ (Fig. $2 a$ ). The final cell yield after $35 \mathrm{~d}$ incubation was approximately $5 \times 10^{7}$ cells $\mathrm{ml}^{-1}$. In comparison to growth under photoautotrophic conditions, addition to the medium of $\mathrm{CsCl}$ to a final concentration of $1 \mathrm{~mm}$ had no apparent effect on either the doubling time or final cell yield during chemoheterotrophic growth (Fig. 2a).

Cells were analysed for intracellular $\mathrm{Cs}^{+}, \mathrm{K}^{+}$and $\mathrm{Na}^{+}$ throughout growth under the two nutritional regimes. Accumulation of $\mathrm{Cs}^{+}$during photoautotrophic growth of $C$. emersonii proceeded in three phases (Fig. 1 b). During the first $6 \mathrm{~d}, \mathrm{Cs}^{+}$accumulated to approximately $16 \mathrm{nmol}$ $\left(10^{6} \text { cells }\right)^{-1}$; this was followed by a slower phase of accumulation to a maximum level of approximately $23 \mathrm{nmol} \mathrm{Cs}^{+}\left(10^{6} \text { cells }\right)^{-1}$ after $20 \mathrm{~d}$, which was then followed by loss of the ion. The final $\mathrm{Cs}^{+}$level present in cells after incubation for $35 \mathrm{~d}$ was approximately $18 \mathrm{nmol}\left(10^{6} \text { cells }\right)^{-1}$. The initial accumulation of $\mathrm{Cs}^{+}$ paralleled a rapid accumulation of $\mathrm{K}^{+}$in cells incubated in the absence of $\mathrm{Cs}^{+}$(Fig. 1c). However, internal $\mathrm{K}^{+}$ levels in cells incubated in the presence of $\mathrm{Cs}^{+}$remained 

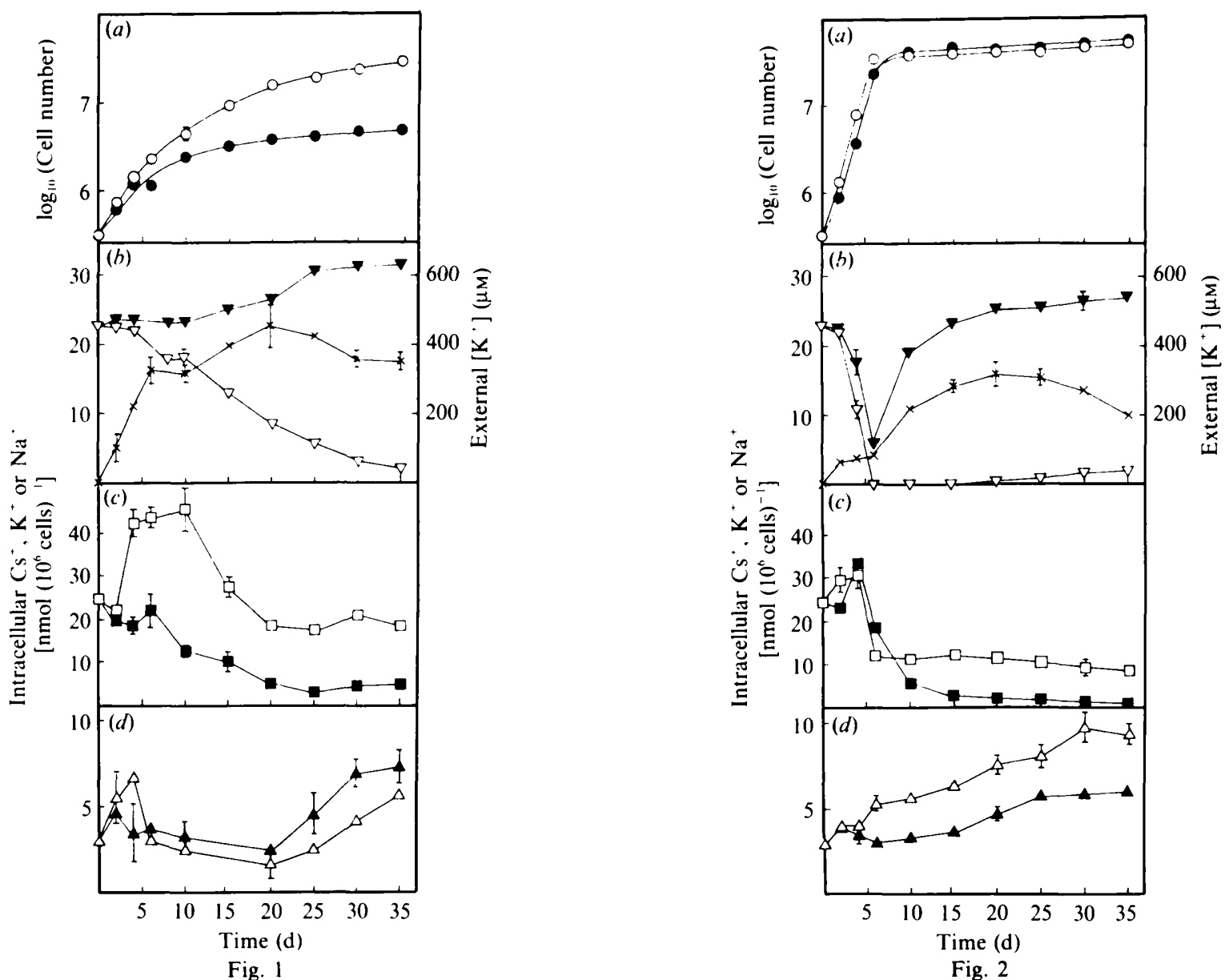

Fig. 1. Effect of caesium accumulation on photoautotrophic growth of Chlorella emersonii and levels of cellular monovalent cations. Cells were grown in the absence (open symbols) or presence (filled symbols) of $1 \mathrm{~mm}-\mathrm{CsCl}$ in the light. $(a) \log _{10}$ cell number $(\mathrm{O}, O)$. (b) Intracellular $\mathrm{Cs}^{+}(\mathrm{x})$ and external $\mathrm{K}^{+}(\nabla, \nabla)$. (c) Intracellular $\mathrm{K}^{+}(\square, \boldsymbol{a})$. (d) Intracellular $\mathrm{Na}^{+}(\Delta, \Delta)$. Mean values from three replicate determinations are shown \pm SEM values where these exceed the dimensions of the symbols.

Fig. 2. Effect of caesium accumulation on chemoheterotrophic growth of Chlorella emersonii and levels of cellular monovalent cations. Cells were grown in the absence (open symbols) or presence (filled symbols) of $1 \mathrm{~mm}-\mathrm{CsCl}$ in the dark with $1 \%(\mathrm{w} / \mathrm{v})$ glucose. Symbols as in Fig. 1.

approximately constant at $20 \mathrm{nmol}\left(10^{6} \text { cells }\right)^{-1}$ during this period and the resulting difference in intracellular $\mathrm{K}^{+}$in cells incubated in the absence and presence of $\mathrm{Cs}^{+}$ was maintained for the remainder of the growth cycle (Fig. 1c). After incubation for $6 \mathrm{~d}$, release of $\mathrm{K}^{+}$occurred from all cells. The loss of $\mathrm{K}^{+}$from cells incubated in the absence of $\mathrm{Cs}^{+}$correlated with $\mathrm{K}^{+}$depletion of the medium as the growth cycle progressed (Fig. $1 b, c$ ). No decrease in extracellular $\mathrm{K}^{+}$concentrations resulted from growth in the presence of $\mathrm{Cs}^{+}$(Fig. $1 b$ ), although the observed loss of internal $\mathrm{K}^{+}$from these cells continued up to $20 \mathrm{~d}$ which coincided with the maximal level of intracellular $\mathrm{Cs}^{+}$(Fig. $\left.1 b, c\right)$. Internal $\mathrm{Na}^{+}$levels remained low throughout photoautotrophic growth of $C$. emersonii and no detectable loss of $\mathrm{Na}^{+}$resulted from $\mathrm{Cs}^{+}$ accumulation (Fig. 1d). However, some increase in $\mathrm{Na}^{+}$ levels was observed after $20 \mathrm{~d}$ incubation of cells with and without $\mathrm{Cs}^{+}$.

Accumulation of $\mathrm{Cs}^{+}$during chemoheterotrophic growth also proceeded in three phases, although these differed quantitatively from those described for photoautotrophically growing cells. An initial phase of uptake decreased in rate as the exponential phase of growth progressed, but after incubation for $6 \mathrm{~d}$, which corresponded with the onset of stationary phase, a marked increase in $\mathrm{Cs}^{+}$accumulation occurred which continued until day 20 to a maximal level of approximately $16 \mathrm{nmol}$ $\left(10^{6} \text { cells }\right)^{-1}$ (Fig. 2b). Subsequently, some loss of intracellular $\mathrm{Cs}^{+}$was observed and the final level attained after growth for $35 \mathrm{~d}$ was approximately $10 \mathrm{nmol} \mathrm{Cs}^{+}\left(10^{6} \text { cells }\right)^{-1}$. Intracellular $\mathrm{K}^{+}$fluctuated considerably over the first $10 \mathrm{~d}$ of growth, although the 

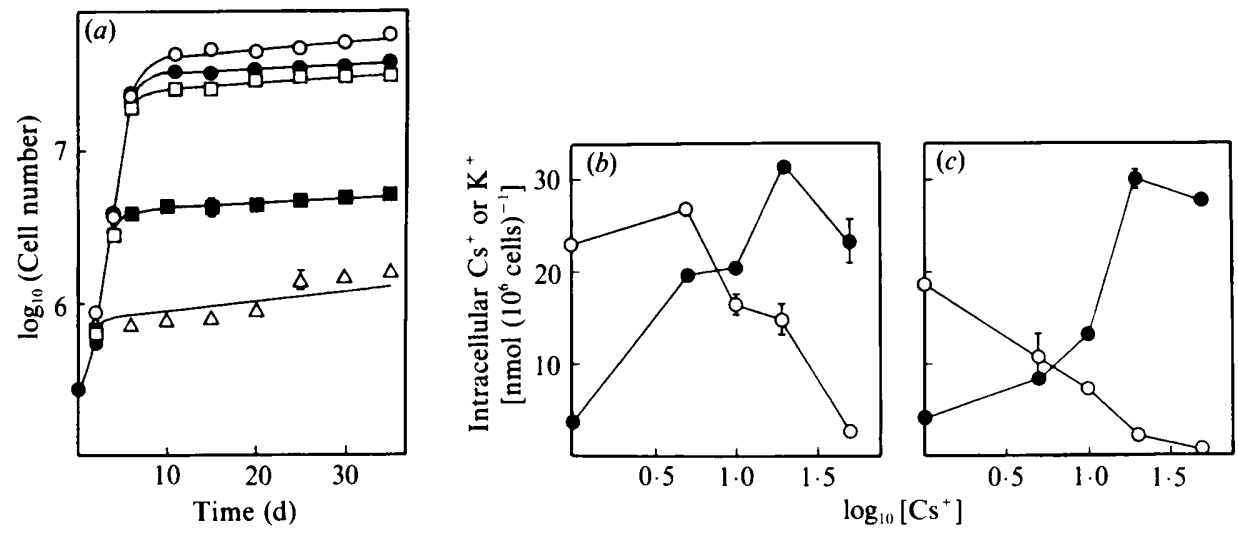

Fig. 3. Effect of increased levels of caesium on chemoheterotrophic growth of Chlorella emersonii. (a) Growth of $C$. emersonii in the dark with $1 \%(\mathrm{w} / \mathrm{v})$ glucose in external $\mathrm{CsCl}$ concentrations $(\mathrm{mM})$ of: $1(O) ; 5(\bigcirc) ; 10(\square) ; 20(\square)$; and $50(\triangle)$. (b,c) Intracellular Cs ${ }^{+}(\bigcirc)$ and $\mathrm{K}^{+}(\mathrm{O})$ levels after growth for $2 \mathrm{~d}(b)$ or $6 \mathrm{~d}(c)$. Mean values from three replicate determinations are shown \pm SEM values where these exceed the dimensions of the symbols.

large accumulation of $\mathrm{K}^{+}$initially observed during photoautotrophic growth of $C$. emersonii (Fig. 1c) was not evident (Fig. $2 c$ ). In contrast, a rapid decline in extracellular $\mathrm{K}^{+}$gave rise to an equally rapid decline in intracellular $\mathrm{K}^{+}$, which occurred between 4 and $10 \mathrm{~d}$ in dividing cells incubated in both the absence and presence of $\mathrm{Cs}^{+}$, (Fig. $2 \mathrm{~b}$ ) and coincided with the onset of stationary phase and the concurrent stimulation of $\mathrm{Cs}^{+}$ accumulation in cells incubated in the presence of $\mathrm{Cs}^{+}$. The increased accumulation of $\mathrm{Cs}^{+}$between 6 and $20 \mathrm{~d}$ resulted in both a further $\mathrm{K}^{+}$loss from cells growing in the presence of $\mathrm{Cs}^{+}$(Fig. 2c) and a sharp rise in the external $\mathrm{K}^{+}$concentration (Fig. $2 b$ ); neither phenomenon was evident in cells growing in the absence of $\mathrm{Cs}^{+}$. As with photoautotrophically growing cells of $C$. emersonii, the excess amount of $\mathrm{K}^{+}$lost from cells growing heterotrophically in the presence of $\mathrm{Cs}^{+}$was generally slightly less than the amount of $\mathrm{Cs}^{+}$accumulated, although here $\mathrm{Cs}^{+}$accumulation resulted in an approximate $35 \%$ decrease in intracellular $\mathrm{Na}^{+}$, which was maintained throughout growth (Fig. $2 d$ ).

To determine concentrations of $\mathrm{Cs}^{+}$that were inhibitory to chemoheterotrophic cultures of $C$. emersonii, cells were grown in the presence of $1,5,10,20$ and $50 \mathrm{~mm}^{-\mathrm{Cs}^{+}}$ (Fig. 3a). Doubling times were similar ( $\sim 0.9 \mathrm{~d})$ at all $\mathrm{Cs}^{+}$ concentrations during the first $2 \mathrm{~d}$ growth. However, the onset of stationary phase was premature, at 5 and $2 \mathrm{~d}$, for cells grown in the presence of 20 and $50 \mathrm{mM}-\mathrm{Cs}^{+}$ respectively. Final cell yields were reduced at all the concentrations tested; by $26 \%$ at $5 \mathrm{~mm}-\mathrm{Cs}^{+}, 39 \%$ at $10 \mathrm{~mm}, 90 \%$ at $20 \mathrm{~mm}$ and by $97 \%$ at $50 \mathrm{~mm}-\mathrm{Cs}^{+}$. Intracellular levels of $\mathrm{Cs}^{+}$and $\mathrm{K}^{+}$after growth for 2 and $6 \mathrm{~d}$ in the presence of these elevated $\mathrm{Cs}^{+}$concentrations are shown in Fig. 3(b,c). The onset of stationary phase for cells incubated in the presence of $50 \mathrm{mM}^{+} \mathrm{Cs}^{+}$ coincided with a marked reduction in internal $\mathrm{K}^{+}$, to approximately $2 \mathrm{nmol}\left(10^{6} \text { cells }\right)^{-1}$, as compared with cells incubated in 10 and $20 \mathrm{mM}-\mathrm{Cs}^{+}[16$ and $14 \mathrm{nmol} \mathrm{K}+$ $\left(10^{6} \text { cells }\right)^{-1}$ respectively] (Fig. $\left.3 b\right)$. Although intracellular $\mathrm{Cs}^{+}$levels after $2 \mathrm{~d}$ were slightly higher for cells incubated in $50 \mathrm{~mm}-\mathrm{Cs}^{+}\left[23 \mathrm{nmol} \mathrm{Cs}{ }^{+}\left(10^{6} \text { cells }\right)^{-1}\right]$ than for those incubated in $10 \mathrm{mM}^{-} \mathrm{Cs}^{+}\left[20 \mathrm{nmol} \mathrm{Cs}{ }^{+}\left(10^{6}\right.\right.$ cells $)^{-1}$ ] they were lower than for those incubated in $20 \mathrm{~mm}^{-\mathrm{Cs}^{+}}\left[31 \mathrm{nmol} \mathrm{Cs}{ }^{+}\left(10^{6} \text { cells }\right)^{-1}\right]$. After $6 \mathrm{~d}$ growth, no change had occurred in the intracellular level of $\mathrm{Cs}^{+}$ for cells incubated in the presence of $20 \mathrm{mM}^{-\mathrm{Cs}^{+}}$ although the onset of growth inhibition at this stage coincided with a marked decline in internal $\mathrm{K}^{+}$to approximately $2 \mathrm{nmol}\left(10^{6} \text { cells) }\right)^{-1}$ (Fig. $3 c$ ). This value was the same as that found for cells incubated in $50 \mathrm{~mm}$ $\mathrm{Cs}^{+}$after $2 \mathrm{~d}$ when inhibition of growth was also apparent, but lower than that in cells incubated in concentrations of $\mathrm{Cs}^{+}$below $20 \mathrm{mM}$, where substantially reduced growth inhibitory effects were evident.

\section{Effect of culture age on the ability of photoautotrophically and chemoheterotrophically grown cell suspensions of $C$. emersonii to accumulate $\mathrm{Cs}^{+}$}

Intracellular $\mathrm{K}^{+}$in photoautotrophically growing cultures of C. emersonii varied throughout growth (Fig. 4a). These fluctuations, however, had little effect on the ability of cells to accumulate $\mathrm{Cs}^{+}$. The amount of $\mathrm{Cs}^{+}$ accumulated by cells of varying culture age, after incubation in buffer for $12 \mathrm{~h}$ in the presence of $1 \mathrm{~mm}$ $\mathrm{Cs}^{+}$, showed only a slight increase from approximately $12 \mathrm{nmol}\left(10^{6} \text { cells }\right)^{-1}$ in cells grown for $5 \mathrm{~d}$, to approximately $17 \mathrm{nmol}\left(10^{6} \text { cells }\right)^{-1}$ in cells grown for $30 \mathrm{~d}$. A decline in intracellular levels of $\mathrm{K}^{+}$occurred in chemoheterotrophically growing cultures of $C$. emersonii, from approximately $19 \mathrm{nmol}\left(10^{6} \text { cells }\right)^{-1}$ after $5 \mathrm{~d}$ to approximately $9 \mathrm{nmol}\left(10^{6} \text { cells }\right)^{-1}$ after $30 \mathrm{~d}$ (Fig. $4 b$ ). However, as with photoautotrophically growing cells the age of these cells had little effect on their ability to accumulate 


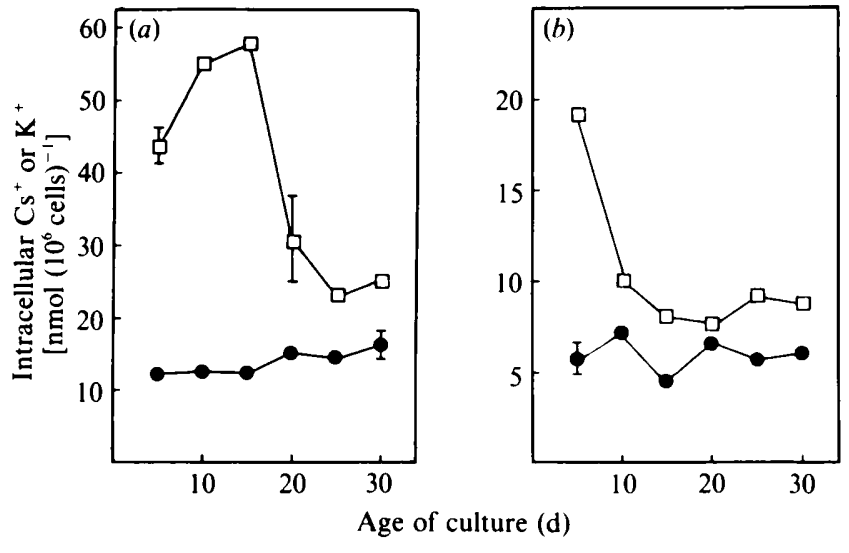

Fig. 4. Effect of culture age on the ability of Chlorella emersonii to accumulate $\mathrm{Cs}^{+}$. Cells of the specified culture age, growing either photoautotrophically $(a)$ or chemoheterotrophically $(b)$ were suspended to $5 \times$ $10^{6} \mathrm{ml}^{-1}$ in $10 \mathrm{~mm}$-HEPES buffer, $\mathrm{pH} 8$, with $1 \mathrm{~mm}$ $\mathrm{CsCl}$ either in the light $(a)$ or in the dark with $1 \%$ $(\mathrm{w} / \mathrm{v})$ glucose $(b)$. The graph shows intracellular $\mathrm{K}^{+}$ prior to the addition of $\mathrm{CsCl}(\square)$ and intracellular $\mathrm{Cs}^{+}$after $12 \mathrm{~h}$ incubation in the presence of $\mathrm{CsCl}$ (O). Mean values from three replicate determinations are shown \pm SEM values where these exceed the dimensions of the symbols.
$\mathrm{Cs}^{+}$. The amount of $\mathrm{Cs}^{+}$accumulated, in the dark with glucose, by chemoheterotrophically grown cells of varying culture age remained approximately constant (Fig. $4 b$ ).

\section{Inhibition of $\mathrm{Cs}^{+}$accumulation by $\mathrm{K}^{+}$and $\mathrm{Na}^{+}$in} photosynthesizing and respiring cells of $C$. emersonii

When $\mathrm{K}^{+}$was supplied to photosynthesizing cells of $C$. emersonii at an equimolar (1 mM) concentration to $\mathrm{Cs}^{+}$, accumulation of $\mathrm{Cs}^{+}$after $12 \mathrm{~h}$ was reduced by approximately $37 \%$ (Table 1 ). When the external concentration of $\mathrm{K}^{+}$was increased to $10 \mathrm{mM}$, and $\mathrm{Cs}^{+}$maintained at $1 \mathrm{mM}$, a $75 \%$ reduction in $\mathrm{Cs}^{+}$accumulation resulted, as compared to cells incubated in the absence of $\mathrm{K}^{+}$. In contrast, when respiring cells of $C$. emersonii were subjected to similar increases in external $\mathrm{K}^{+}$concentrations, approximate reductions in $\mathrm{Cs}^{+}$accumulation were only $30 \%\left(1 \mathrm{mM}-\mathrm{K}^{+} ; 1 \mathrm{mM}-\mathrm{Cs}^{+}\right)$and $50 \%\left(10 \mathrm{mM}-\mathrm{K}^{+}\right.$; $\left.1 \mathrm{mM}-\mathrm{Cs}^{+}\right)$.

The effect of externally supplied $\mathrm{Na}^{+}$on $\mathrm{Cs}^{+}$accumulation differed from that of $\mathrm{K}^{+}$. When $\mathrm{Na}^{+}$was supplied at equimolar ( $1 \mathrm{mM})$ concentrations to $\mathrm{Cs}^{+}$a slight stimulation of $\mathrm{Cs}^{+}$accumulation was evident, and only when a 50 -fold higher $\mathrm{Na}^{+}$concentration was present did significant inhibition of $\mathrm{Cs}^{+}$accumulation occur in both photosynthesizing $(27 \%$ reduction) and respiring $(20 \%$ reduction) cells. $\mathrm{Cs}^{+}$accumulation was virtually eliminated in both cases in the presence of $0.5 \mathrm{M}-\mathrm{Na}^{+}$(Table 1$)$.

\section{Effect of $\mathrm{Cs}^{+}$accumulation and $\mathrm{K}^{+}$loss on rates of photosynthesis and respiration in $C$. emersonii}

The photosynthetic and respiratory rates of cells of $C$. emersonii in the exponential phase of photoautotrophic and chemoheterotrophic growth were measured prior to, and after, incubation for $12 \mathrm{~h}$ in the absence and presence of $10 \mathrm{mM}^{-} \mathrm{Cs}^{+}$(Table 2); this high $\mathrm{Cs}^{+}$ concentration was employed to produce a rapid detectable change in oxygen evolution/uptake rates. Incubation of cells for $12 \mathrm{~h}$ in the presence of $\mathrm{Cs}^{+}$resulted in rates of photosynthesis and respiration similar to those observed with cells incubated in the absence of $\mathrm{Cs}^{+}$. However, the rates of photosynthesis decreased by

Table 1. Effect of $\mathrm{K}^{+}$and $\mathrm{Na}^{+}$on $\mathrm{Cs}^{+}$accumulation in Chlorella emersonii during photosynthesis and respiration

Photoautotrophically grown cells were suspended to $5 \times 10^{6} \mathrm{ml}^{-1}$ in $10 \mathrm{mM}$-HEPES buffer, $\mathrm{pH} 8$, supplemented with $1 \mathrm{mM}-\mathrm{CsCl}$ and the appropriate amount of $\mathrm{K}^{+}$or $\mathrm{Na}^{+}$. Cells were harvested after $12 \mathrm{~h}$ incubation either in the light or in the dark with $1 \%(\mathrm{w} / \mathrm{v})$ glucose. Mean values from three replicate determinations are shown \pm SEM.

\begin{tabular}{cccc}
\hline \hline $\begin{array}{c}\text { Metal cation added } \\
\text { to external medium }\end{array}$ & $\begin{array}{c}\text { Concn } \\
(\mathrm{mM})\end{array}$ & $\begin{array}{c}\text { Intracellular Cs } \mathrm{Cs}^{+} \text {in } \\
\text { photosynthesizing cells } \\
\text { [nmol }\left(10^{6} \text { cells }\right)^{-1} \text { ] }\end{array}$ & $\begin{array}{c}\text { Intracellular Cs }{ }^{+} \text {in } \\
\text { respiring cells } \\
\text { [nmol }\left(10^{6} \text { cells }\right)^{-1} \text { ] }\end{array}$ \\
\hline None & - & $12.4 \pm 0.2$ & $6.0 \pm 0.2$ \\
$\mathrm{~K}^{+}$ & 1 & $7.8 \pm 0.0$ & $4 \cdot 2 \pm 0.0$ \\
& 10 & $3.1 \pm 0.2$ & $3.0 \pm 0.3$ \\
$\mathrm{Na}^{+}$ & 1 & $13.6 \pm 0.2$ & $8.5 \pm 0.3$ \\
& 10 & $10 \cdot 2 \pm 0.6$ & $7.9 \pm 0.0$ \\
& 50 & $9 \cdot 1 \pm 0.2$ & $4.8 \pm 0.0$ \\
& 500 & $0.7 \pm 0.3$ & $0.3 \pm 0.0$ \\
\hline \hline
\end{tabular}


Table 2. Effect of $\mathrm{Cs}^{+}$accumulation and $\mathrm{K}^{+}$loss on rates of photosynthesis and respiration in Chlorella emersonii

Cells were harvested from the late exponential phase of either photoautotrophic or chemoheterotrophic growth and suspended to $5 \times 10^{6}$ $\mathrm{ml}^{-1}$ in $10 \mathrm{mM}$-HEPES buffer, $\mathrm{pH} \mathrm{8} \pm 10 \mathrm{mM}-\mathrm{CsCl}$. Cells were harvested after 0 and $12 \mathrm{~h}$ incubation in the light (for photosynthesis) or in the dark with $1 \%(w / v)$ glucose (for respiration). Mean values from three replicate determinations are shown \pm SEM.

\begin{tabular}{|c|c|c|c|c|c|}
\hline Treatment & $\begin{array}{l}\text { Time of incubation } \\
\text { (h) }\end{array}$ & $\begin{array}{l}\mathrm{Cs}^{+} \text {concn } \\
(\mathrm{mM})\end{array}$ & $\begin{array}{c}\text { Intracellular } \mathrm{K}^{+} \\
\text {[nmol }\left(10^{6} \text { cells }\right)^{-1} \text { ] }\end{array}$ & $\begin{array}{l}\text { Intracellular } \mathrm{Cs}^{+} \\
{\left[\mathrm{nmol}\left(10^{6} \text { cells }\right)^{-1}\right]}\end{array}$ & $\begin{array}{c}\text { Rate of } \\
\text { photosynthesis/ } \\
\text { respiration } \\
{\left[\mathrm{nmol} \mathrm{O}_{2} \mathrm{~min}^{-1}\right.} \\
\left.\left(10^{6} \mathrm{cells}\right)^{-1}\right]\end{array}$ \\
\hline Light & $\begin{array}{r}0 \\
12 \\
12\end{array}$ & $\begin{array}{r}0 \\
0 \\
10\end{array}$ & $\begin{array}{l}46.6 \pm 3.5 \\
26.6 \pm 1.4 \\
10.9 \pm 0.7\end{array}$ & $\begin{array}{c}0 \\
0 \\
36.5 \pm 1.0\end{array}$ & $\begin{array}{l}2.88 \pm 0.10 \\
0.93 \pm 0.18 \\
1.05 \pm 0.10\end{array}$ \\
\hline Dark + glucose & $\begin{array}{r}0 \\
12 \\
12\end{array}$ & $\begin{array}{r}0 \\
0 \\
10\end{array}$ & $\begin{array}{r}27.2 \pm 1.0 \\
25.0 \pm 0.8 \\
7.9 \pm 0.8\end{array}$ & $\begin{array}{c}0 \\
0 \\
22 \cdot 8 \pm 2 \cdot 7\end{array}$ & $\begin{array}{l}0.85 \pm 0.01 \\
0.85 \pm 0.03 \\
0.80 \pm 0.02\end{array}$ \\
\hline
\end{tabular}

approximately $66 \%$ over the incubation period, whilst those of respiration remained approximately constant. Analysis of intracellular $\mathrm{K}^{+}$levels at 0 and $12 \mathrm{~h}$ revealed that $\mathrm{K}^{+}$loss occurred from both photosynthesizing and respiring cells incubated in the presence of $\mathrm{Cs}^{+}$; however, a reduction in internal $\mathrm{K}^{+}$was also evident in photosynthesizing cells incubated in the absence of $\mathrm{Cs}^{+}$ that did not occur in respiring cells. Thus an approximate $71 \% \mathrm{Cs}^{+}$-induced decrease in intracellular $\mathrm{K}^{+}$had no effect on the rate of respiration whereas decreases of both $44 \%$ and $77 \%$ in intracellular $\mathrm{K}^{+}$from photosynthesizing cells, incubated in the absence and presence of $\mathrm{Cs}^{+}$ respectively, correlated with an approximate $66 \%$ reduction in the rate of photosynthesis. $\mathrm{Cs}^{+}$accumulation occurred in both photosynthesizing and respiring cells and was slightly greater than the concurrent $\mathrm{K}^{+}$ release in both cases.

\section{Discussion}

During both photoautotrophic and chemoheterotrophic growth of algae certain cell components are required to metabolize sugars. However, the diversion of a large fraction of such components to the catalysis of phototrophy during photoautotrophic growth results in an intrinsically slower growth rate, which, according to Raven (1988), may be as great as 2-fold. This is in agreement with the results presented here for $C$. emersonii, where an approximate $1 \cdot 8$-fold increase in maximal growth rate occurred when cells were grown chemoheterotrophically as opposed to photoautotrophically. These differences in growth under the two nutritional regimes coincided with differential sensitivities to $\mathrm{Cs}^{+}$. The extent of inhibition of photoautotrophic growth of $C$. emersonii in the presence of $1 \mathrm{mM}-\mathrm{Cs}^{+}$was similar to that found for the cyanobacterium Synechocystis PCC 6803 under the same conditions (Avery et al., 1991), although $1 \mathrm{mM}^{-\mathrm{Cs}^{+}}$had no effect on chemohetero- trophic growth of C. emersonii. Avery et al. (1991) suggested that $\mathrm{Cs}^{+}$accumulation resulted in suppression of growth through replacement of cellular $\mathrm{K}^{+}$. If this was the case here, a simple explanation can be proposed for the present observations according to the stage of growth at which $\mathrm{Cs}^{+}$-induced $\mathrm{K}^{+}$loss from cells occurred during chemoheterotrophy and photoautotrophy. The decrease in intracellular $\mathrm{K}^{+}$, associated with initial rapid cell division and exhaustion of external $\mathrm{K}^{+}$, during chemoheterotrophic growth of $C$. emersonii, could not be distinguished from $\mathrm{K}^{+}$loss due to $\mathrm{Cs}^{+}$accumulation until day 10 when cell division had ceased. In contrast, $\mathrm{Cs}^{+}$ accumulation resulted in decreased internal $\mathrm{K}^{+}$during the exponential phase of photoautotrophic growth and therefore had a pronounced effect on initial cell doubling times.

When C. emersonii was grown chemoheterotrophically in the presence of increased levels of $\mathrm{Cs}^{+}$, only at $20 \mathrm{mM}-$ $\mathrm{Cs}^{+}$was the final cell yield reduced by an amount approximating to that found for cells grown photoautotrophically in the presence of $1 \mathrm{mM}-\mathrm{Cs}^{+}$. The internal $\mathrm{Cs}^{+}$and $\mathrm{K}^{+}$levels in cells grown chemoheterotrophically at $20 \mathrm{mM}-\mathrm{Cs}^{+}$, both prior to $(2 \mathrm{~d})$, and at the point of, inhibition of cell division ( $6 \mathrm{~d})$, are revealing. Over this period cellular $\mathrm{Cs}^{+}$remained constant whereas cellular $\mathrm{K}^{+}$dropped to a level presumably below that needed to support the requirements for cell division. These results clearly demonstrate that it was not the presence of $\mathrm{Cs}^{+}$in the cell that was inhibitory to chemoheterotrophic growth, but rather the resultant loss of cellular $\mathrm{K}^{+}$, as only the intracellular concentration of the latter ion changed between 2 and $6 \mathrm{~d}$. Furthermore, it can be inferred that the threshold level of $\mathrm{K}^{+}$, below which chemoheterotrophic cell division ceased, lies between 2 and $7 \mathrm{nmol} \mathrm{K} \mathrm{K}^{+}\left(10^{6} \text { cells }\right)^{-1}$ and at all levels higher than this the rate of cell division remained approximately constant. This is in contrast to photoautotrophic growth where the rate of cell division after $4 \mathrm{~d}$ was reduced by 
approximately $35 \%$ when cells, grown in the presence of $1 \mathrm{mM}^{-\mathrm{Cs}^{+}}$, contained $19 \mathrm{nmol} \mathrm{K}^{+}\left(10^{6} \text { cells }\right)^{-1}$, in comparison to control cells containing $42 \mathrm{nmol} \mathrm{K}^{+}$ $\left(10^{6} \text { cells }\right)^{-1}$. It must be stressed that possible differences in the volume of cells growing under the two nutritional regimes were not discernible through microscopic examination. The results therefore contradict those of Eyster et al. (1958), who reported that a 10-fold higher $\mathrm{K}^{+}$concentration was required for chemoheterotrophic growth of Chlorella pyrenoidosa than for photoautotrophic growth, although the authors admitted that their results showed 'questionable variation'.

In short-term experiments, incubation of C. emersonii in the dark with glucose supported a lower accumulation of $\mathrm{Cs}^{+}$than incubation in the light. The reverse of this situation was found for $\mathrm{Rb}^{+}$influx in $C$. pyrenoidosa (Springer-Lederer \& Rosenfeld, 1968) although these workers conducted uptake experiments at a lower $\mathrm{pH}$ value of 6.5 . It has since been shown that a switch from $\mathrm{K}^{+} / \mathrm{K}^{+}$to $\mathrm{K}^{+} / \mathrm{H}^{+}$exchange, and hence an increased net $\mathrm{K}^{+}$uptake, is necessary to maintain high internal $\mathrm{pH}$ levels when glucose is provided as an organic carbon source for Chlorella fusca (Tromballa, 1981). The requirement for such a mechanism to maintain a constant $\Delta \mathrm{pH}$ would probably not be so great at lower external $\mathrm{pH}$ values suggesting that a reduced $\mathrm{K}^{+}$(or $\mathrm{Rb}^{+}$) accumulation would result. It is more likely that the observed discrepancy may result from a $\mathrm{K}^{+} / \mathrm{H}^{+}$exchange system operating during respiration being more selective for $\mathrm{K}^{+}$(or $\mathrm{Rb}^{+}$) and against $\mathrm{Cs}^{+}$than a $\mathrm{K}^{+} / \mathrm{K}^{+}$exchange operating during photosynthesis. The $\mathrm{K}^{+} / \mathrm{H}^{+}$exchange observed in Chlorella cells grown on low-salt media (Schaedle \& Jacobsen, 1965) has been described as occurring via a higher-affinity $\mathrm{K}^{+}$-transport system than that involved with $\mathrm{K}^{+} / \mathrm{K}^{+}$exchange (Raven, 1980) and one which would presumably select more strongly against $\mathrm{Cs}^{+}$.

Despite the observed large variations in internal $\mathrm{K}^{+}$ through both chemoheterotrophic and photoautotrophic growth of $C$. emersonii in the absence of $\mathrm{Cs}^{+}$, the effect of growth stage and internal $\mathrm{K}^{+}$levels on the ability of cells to accumulate $\mathrm{Cs}^{+}$was negligible. It is likely that the observed changes in $\mathrm{Cs}^{+}$accumulation through growth in batch culture were primarily due to fluctuations in external $\mathrm{K}^{+}$concentration, although $\mathrm{pH}$ changes of the medium may also play a role (Avery et al., 1991). Williams (1960) described an increased $\mathrm{Cs}^{+}$uptake in cells of Euglena intermedia in the stationary phase of growth and it is probable that this may have been due to a depletion of $\mathrm{K}^{+}$from the medium. The inhibition of $\mathrm{Cs}^{+}$uptake by external $\mathrm{K}^{+}$has been reported previously for Chlorella spp. (Williams \& Swanson, 1958; Williams, 1960; Plato \& Denovan, 1974). The results presented here imply that this inhibition is greater for cells metabolizing photoautotrophically than chemoheterotrophically. The evidence discussed above precludes the possibility that the $\mathrm{K}^{+} / \mathrm{H}^{+}$exchange that operates during metabolism of glucose in Chlorella (Tromballa, 1981) has a lower selectivity than the $\mathbf{K}^{+} / \mathbf{K}^{+}$exchange that operates during photosynthesis and consequently the reason for this differential sensitivity to $\mathrm{K}^{+}$is unknown. External $\mathrm{Na}^{+}$had a much lower effect on $\mathrm{Cs}^{+}$accumulation than $\mathrm{K}^{+}$and in fact a slight stimulation of $\mathrm{Cs}^{+}$ uptake was evident at the lower concentrations of $\mathrm{Na}^{+}$ studied. Stimulation of monovalent cation uptake by $\mathrm{Na}^{+}$has previously been described in yeast (BorstPauwels et al., 1973). The observed depression of $\mathrm{Cs}^{+}$ accumulation at elevated $\mathrm{Na}^{+}$concentrations is in agreement with the results of Williams (1960) with Euglena intermedia who attributed the observation to an alteration of plasma membrane permeability by $\mathrm{Na}^{+}$ rather than by its antagonistic effect in the metabolic pool.

The observed strong inhibition of $\mathrm{O}_{2}$ evolution from photosynthesizing $C$. emersonii was concurrent with $\mathrm{K}^{+}$ loss from cells incubated in buffer in both the absence and presence of $\mathrm{Cs}^{+}$. Loss of $\mathrm{K}^{+}$under similar conditions in the absence of $\mathrm{Cs}^{+}$has been reported previously for cyanobacteria (Avery et al., 1991) and yeast (Norris et al., 1976). In marked contrast to photosynthesis, no depression of respiration rate resulted from loss of $\mathrm{K}^{+}$, and this was the case even when the decrease in cellular $\mathrm{K}^{+}$under the latter conditions was greater than that which resulted in inhibition of photosynthesis. It is significant that the lower value of $\mathrm{K}^{+}$in respiring cells observed here $\left[7.9 \mathrm{nmol}\left(10^{6} \text { cells }\right)^{-1}\right]$ was slightly higher than that estimated earlier as being the threshold below which inhibition of chemoheterotrophic cell division results. These results are generally in agreement with those found for chemoheterotrophic and photoautotrophic growth of $C$. emersonii and imply that although the presence of $\mathrm{Cs}^{+}$itself in the cell may not be inhibitory, the resultant loss of $\mathrm{K}^{+}$is. Photosynthesis and photoautotrophic growth are substantially more sensitive to loss of $\mathrm{K}^{+}$, and hence $\mathrm{Cs}^{+}$accumulation, than respiration and chemoheterotrophic growth. Whilst it is clear that different $\mathrm{K}^{+}\left(\mathrm{Cs}^{+}\right)$uptake systems may operate according to the mode of metabolism of $C$. emersonii, it remains unclear why there is a greater requirement for $\mathrm{K}^{+}$in photosynthesizing cells. $\mathrm{K}^{+}$is primarily required by microbial cells as an osmotic regulator, a regulator of internal $\mathrm{pH}$ and as an enzyme activator (Walderhaug $e t$ al., 1987). Several enzymes have been identified as having a requirement for $\mathrm{K}^{+}$(Suelter, 1970) and it is possible that the additional enzymes required for the catalysis of phototrophy, that are not necessary during chemoheterotrophy, may have a greater requirement for $\mathrm{K}^{+}$than those which catalyse the breakdown of sugars. 
S. V.A. gratefully acknowledges receipt of a Natural Environment Research Council (NERC) postgraduate research studentship.

\section{References}

Avery, S. V., Codd, G. A. \& Gadd, G. M. (1991). Caesium accumulation and interactions with other monovalent cations in the cyanobacterium Synechocystis PCC 6803. Journal of General Microbiology 137, 405-413.

BARBER, J. (1968a). Light induced uptake of potassium and chloride by Chlorella pyrenoidosa. Nature, London 217, 876-878.

BARBER, J. (1968b). The influx of potassium into Chlorella pyrenoidosa. Biochimica et Biophysica Acta 163, 141-149.

BENNETT, W. N. (1990). Measurement of manganese amelioration of cadmium toxicity in Chlorella pyrenoidosa using turbidostat culture. Archives of Environmental Contamination and Toxicology 19, 118123.

Borst-PaUWELS, G. W. F. H. (1981). Ion transport in yeast. Biochimica et Biophysica Acta 650, 88-127.

Borst-Pauwels, G. W. F. H., Schnetkamp, P. \& Van Well, P. (1973). Activation of $\mathrm{Rb}^{+}$and $\mathrm{Na}^{+}$uptake into yeast by monovalent cations. Biochimica et Biophysica Acta 291, 274-279.

Bossemeyer, D., Schlösser, A. \& BaKker, E. P. (1989). Specific cesium transport via the Escherichia coli $\mathrm{Kup}$ (TrkD) $\mathrm{K}^{+}$uptake system. Journal of Bacteriology 171, 2219-2221.

Cambray, R. S., Cawse, P. A., Garland, J. A., Gibson, J. A. B., Johnson, P., Lewis, G. N. J., Newton, D., Salmon, L. \& Wade, B. O. (1987). Observations on radioactivity from the Chernobyl accident. Nuclear Energy 26, 77-101.

Droop, M. R. (1974). Heterotrophy of carbon. In Algal Physiology and Biochemistry, pp. 530-559. Edited by W. D. P. Stewart. Oxford: Blackwell Scientific Publications.

ElstNer, E. F., FinK, R., Höll, W., Lengfelder, E. \& Ziegler, H. (1987). Natural and Chernobyl-caused radioactivity in mushrooms, mosses and soil samples of defined biotopes in SW Bavaria. Oecologia 73, 553-558.

Eyster, H. C., Brown, T. E. \& TANner, H. A. (1958). Mineral requirements for Chlorella pyrenoidosa under autotrophic and heterotrophic conditions. In Trace Elements; pp. 157-174. Edited by C. A. Lamb, O. G. Bentley \& J. M. Beattie. New York: Academic Press.

GADD, G. M. (1988). Accumulation of metals by microorganisms and algae. In Biotechnology, vol. 6b, Special Microbial Processes, pp. 401433. Edited by H.-J. Rehm. Weinheim: VCH Verlagsgesellschaft.

GADD, G. M. (1990). Metal tolerance. In Microbiology of Extreme Environments, pp. 178-210. Edited by C. Edwards. Milton Keynes: Open University Press.

Golterman, H. L. (1969). Methods for Chemical Analysis of Fresh Waters. Oxford: Blackwell Scientific Publications.

Greenwood, N. N. \& Earnshaw, A. (1984). Chemistry of the Elements. Oxford: Pergamon Press.
Hughes, M. N. \& Poole, R. K. (1989). Metals and Microorganisms. London: Chapman \& Hall.

KanNan, S. (1971). Plasmalemma: The seat of dual mechanisms of ion absorption in Chlorella pyrenoidosa. Science 173, 927-929.

Khummongkol, D., Canterford, G. S. \& Fryer, C. (1982). Accumulation of heavy metals in unicellular algae. Biotechnology and Bioengineering 24, 2643-2660.

Mahan, C. A., Majidi, V. \& Holcombe, J. A. (1989). Evaluation of metal uptake of several algae strains in a multicomponent matrix utilizing inductively coupled plasma emission spectrometry. Analytical Chemistry 61, 624-627.

Nakajima, A., Horikoshi, T. \& Sakaguchi, T. (1981). Studies on accumulation of heavy metal elements in biological systems selective accumulation of heavy metal ions by Chlorella regularis. European Journal of Applied Microbiology and Biotechnology 12, 7683.

Norris, P., Kee Man, W., Hughes, M. N. \& Kelly, D. P. (1976). Toxicity and accumulation of thallium in bacteria and yeast. Archives of Microbiology 110, 279-286.

PASCHINGer, H. \& VANICEK, T. (1974). Effects of gamma irradiation on the two mechanisms of $\mathrm{Rb}(\mathrm{K})$ uptake by Chlorella. Radiation Botany 14, 301-307.

Plato, P. \& Denovan, J. T. (1974). The influence of potassium on the removal of ${ }^{137} \mathrm{Cs}$ by live Chlorella from low level radioactive wastes Radiation Botany 14, 37-41.

Raven, J. A. (1980). Nutrient transport in microalgae. Advances in Microbial Physiology 21, 47-226.

RAVEN, J. A. (1988). Limits to growth. In Micro-algal Biotechnology, pp. 331-356. Edited by M. A. Borowitzka \& L. J. Borowitzka Cambridge: Cambridge University Press.

SCHAEDLE, M. \& JACOBSEN, L. (1965). Ion absorption and retention by Chlorella pyrenoidosa. I. Absorption of potassium. Plant Physiology 40, 214-220.

Solt, J., Paschinger, H. \& Broda, E. (1971). Die energieabhängige aufnahme von thallium durch Chlorella. Planta 101, 242-250.

SPRINGER-LEDERER, H. \& RosenFeLD, D. L. (1968). Energy sources for the absorption of rubidium by Chlorella. Physiologia Plantarum 21, 435-444.

Stanier, R. Y., Kunisawa, R., Mandel, M. \& Cohen-Bazire, G (1971). Purification and properties of unicellular blue-green algae (order Chroococcales). Bacteriological Reviews 32, 171-205.

Suelter, C. H. (1970). Enzymes activated by monovalent cations. Science 168, 789-795.

Tromballa, H. W. (1981). The effect of glucose on potassium transport by Chlorella fusca. Zeitschrift für Pflanzenphysiologie 105, 1-10.

Walderhaug, M. O., Dosch, D. C. \& Epstein, W. (1987). Potassium transport in bacteria. In Ion Transport in Prokaryotes, pp. 85-130. Edited by B. P. Rosen \& S. Silver. New York: Academic Press.

Watson, J. S., Scott, C. D. \& Faison, B. D. (1989). Adsorption of $\mathrm{Sr}$ by immobilized microorganisms. Applied Biochemistry and Biotechnology 20/21, 699-709.

Williams, L. G. (1960). Uptake of cesium ${ }^{137}$ by cells and detritus of Euglena and Chlorella. Limnology and Oceanography 5, 301-311.

Williams, L. G. \& Swanson, H. D. (1958). Concentration of cesium137 by algae. Science $127,187-188$. 